maximum productivity upon which the prosperity of all depend.

The conference will be reported in full in the January issue of the British Journal of Industrial Medicine. The Society is arranging another conference at the London School of Hygiene and Tropical Medicine, on April 6, 1954, when the subject will be on the maximum allowable concentrations of toxic and dangerous air contaminants.

\section{N. Davres}

\section{INTERNATIONAL SCIENTIFIC FILM ASSOCIATION}

\section{ANNUAL CONGRESS IN LONDON}

$\mathrm{T}$

HE seventh annual congress of the International Scientific Film Association was held during September 18-26 in London on the South Bank, the meetings of the general assembly and specialized groups being in the Royal Festival Hall and the afternoon and evening scientific film shows being in the National Film Theatre. More than one hundred delegates and observers from twenty-two countries and from international bodies (such as Unesco) attended, together with a large number of visitors. At the various sessions more than two hundred and twenty films were shown from twenty-four countries, including some seventy medical films. During the congress Canada and Morocco were made members of the Association.

The congress was opened at the gala première film show on the evening of September 18 by Sir Walter Monckton, Minister of Labour and National Service, who paid tribute to the Scientific Film Association of Great Britain for its work in organizing the congress and for its services to industry generally. The films shown at this performance included contributions from India ("National Physical Laboratory"), Great Britain ("The Desert Locust"; World Wide Pictures, Ltd.), Hungary ("Blossom Time till Autumn Frost"; a remarkable Nature film by HomokiNagy), Australia ("Pre-stressed Concrete Tower"), Canada ("Embryonic Development-the Chick"; J. V. Durden), Belgium ("Combat avec l'Ombre"), U.S.S.R. ("Life in the Arctic"; Moscow Popular Science Film Studio, directed by A. Zguridi) and France ("Flammes du Soleil"; Paris Observatory, produced by Jean Painlevé and directed by Joseph Leclerc).

The next day the general assembly met, appointed working committees and transacted the internal business of the Association, adopting the honorary secretary's report and the balance sheet. The congress then divided into its various specialized groups which held meetings during the following six days.

The Research Group held four meetings, two of which were jointly with the Medical and Industrial Groups, respectively. Its first meeting was on the morning of September 20, when three films of research interest were shown and discussed. The first, "Growth of Crystals" (France; Jean Dragescu), used time-lapse and polarized-light techniques to study the crystallization of various stable and unstable substances. The second, "Waters of Coweeta" (United States), was an impressive record of forestry research based on the long-term analysis and measurement of the run-off from watersheds under different conditions. The third, "Biology of the Hamster" (Western Germany; Dr. Gotthard Wolf), was part of a German plan to make an encyclopædia of film and was a complete record of one animal's behaviour during a typical chain of circumstances.

The second research session, jointly with the Industrial Group, was on September 22, when the main subject was "High Speed Films in Industrial Research". There were five contributions-two French and three British. M. Galey, of the Institut de Recherches de la Sidérurgie, showed a film used for investigating the interior of a Martin furnace; it was interesting to compare this with the British contribution by Mr. C. Burns (British Iron and Steel Research Association), who showed a three-dimensional film made to investigate the movements of air and coke particles inside a blast furnace. The technique used enabled actual measurements of high accuracy to be made of the size and shape of the cavity caused by the air blast, and provided a good example of the way films can be used to investigate subjects which cannot be explored by other methods. Mr. John Rogers (Building Research Station) read a paper, illustrated by film, on the uses of the film in building research, which included an interesting description of the use of films in investigating problems of fluid flow. There were a French and a British contribution illustrating railway research : M. Censier, chief of the cinema service of the French national railways, introduced a film showing the use of the high-speed camera on the French railways to investigate speed and wear tests; and Mr. J. C. Lucas (Railway Executive Research Department) showed a film made to investigate a condition of rail wear on electric tracks known as 'periodic side-cutting'.

The third session, on September 23, with Dr. G. Wolf presiding, was a joint meeting with the Medical Group to discuss image converter techniques. Papers were read by Dr. J. S. Courtney-Pratt (University of Cambridge) on the use of image converter tubes in high-speed photography, Mr. A. E. Sarson (Marconi, Ltd.) on the application of television to cinematography and Dr. W. J. Oosterkamp (Philips, Netherlands) on a new X-ray intensifier.

The final research session was on September 26, at the Shell Film Unit, under the chairmanship of Dr. J. Frédéric (Belgium). Ten films were shown andvery briefly-discussed. They included M. R. G. Busnel (France) introducing a film "Enregistrements par une technique electro-accoustique de movements de faible amplitude : applications à la physiologie et la pharmaco-dynamie", which depicted the measurement of small pulsations (beating of a frog's heart, blood vessels in a mouse's foot, etc.) by an apparatus devised by Busnel and Pasquinelly, and amplified and recorded by an oscillograph. Dr. Frédéric showed his film "Recherche experimentale de Chondriome", investigating and recording movements of mitochrondria when treated with various reagents. Dr. W. Rogers (East Malling) presented "The Freezing of Plant Tissues", which attracted great interest and applause.

Other events during the congress were a wellplanned series of industrial sessions, covering the use of films on vocational guidance, training of personnel, motion study and industrial welfare; a conference on the dissemination of science by television, under the chairmanship of Mrs. Mary Adams; a morning session on education addressed by Dr. J. Harrison (Educational Foundation for Visual Aids) and Dr. 
H. D. Turner (Extra-mural Department, University of Sheffield); and a session on stereoscopy with Prof. W. D. Wright (Imperial College of Science and Technology, London) in the chair.

During the congress, the general assembly resolved to approach the International Federation of Film Archives to secure international co-operation in the preservation of films relevant to the history of science and technology, and also decided to urge its constituent national organizations to approach their respective governments with proposals for facilitating the interchange of scientific films between different countries.

At the concluding session of the assembly, held on September 26, the officers of the Association for 1953-54 were elected as follows: President, Jean Painlevé (France); Vice-Presidents, Jan Korngold (Poland) and Prof. Mario Ponzo (Italy) ; Honorary Treasurer, J. W. Varossieau (Netherlands); and Honorary Secretary, John Maddison (Great Britain). Sir Arthur Elton, leading the British delegation, paid a warm tribute to the retiring president, John Maddison, for his five years of service in that office.

The eighth annual congress of the Association will be held in Rome during October 1954.

J. Stewart Cook

\section{THE CHILDREN'S FILM FOUNDATION}

$\mathrm{T}$

HE Children's Film Foundation was set up in 1951 with the object of "ensuring the production, distribution and exhibition of special entertainment films for children". 'The Foundation does not make its own films, but from its own selected programmes it offers each film to those production companies competent to deal with the themes involved. The chosen company then produces the film for a fixed fee and under the supervision of the Foundation. So far, nineteen different companies have produced films for the Foundation.

The Foundation is a non-profit-making organization financed from the British Film Production Fund, Ltd. Its directors are nominated by the British film trade associations, which also elect an independent chairman. Miss Mary Field, the well-known pioneer in children's and Nature films, is the executive officer; and Mr. W. G. R. Thom is secretary and business manager.

Cinemas which organize children's elubs and matinees have agreed to exhibit the Foundation's films in rotation, and five complete programmes are now circulating in Great Britain.

The films so far completed include eight features (one hour each), eight short stories (twenty minutes), eight "Our Magazine" (ten minutes), one novelty (ten minutes), and four pen pictures (ten minutes)a splendid record for two to three years of work.

The most recent programme of the Foundation's films was presented at the Odeon Cinema, Kensington, London (by permission of the J. Arthur Rank Organization), on December 12 before a packed audience of children which was also graced by the presence of H.R.H. Princess Alice and many local dignitaries. The programme, which lasted two hours altogether, was preceded by an episode of a serial and a cartoon. Then followed one each of the Foundation's latest pen picture, comedy and feature films.

The pen picture is included in these programmes to conform to the Foundation's policy of producing a balanced programme and so including one or more films suitable for children less than nine years of age. The one shown, "A Letter from Wales", took the form of a pictorial letter written by a village boy to a relative abroad. It was obvious that the young audience was intensely interested and were, perhaps subconsciously, learning some human geography. The comedy, "A Good Pull-up", was good fun.

The feature film, "The Secret Cave", was excellent from all points of view. The play was based on Thomas Hardy's "Our Exploits at West Poley". So far as is known, this is the only story Hardy deliberately addressed to juvenile readers. It was commissioned by an American magazine in 1883, but never published. The manuscript remained in the United States and was rediscovered in 1951, when it was published in Britain. For the purpose of the film, the scenes are set on and under the Mendip Hills in Somerset. The underground scenes were made in the famous Wookey Hole Caves. There can be nothing but praise for this excellent children's film from the points of view of open entertainment and subtle teaching. 'The children followed an exciting story while revelling in the beautiful Mendip scenery, glimpses of Somerset life and the thrill of underground caverns. (The film writer, Mr. J. Mendoza, might have slipped in a verbal picture of the Glaston. bury Thorn and the earliest days of Christianity in Britain when one of his juvenile characters is pointing out a very characteristic view of Glastonbury Tor across the Somersetshire plain.)

These three films revealed what excellent work the Children's Film Foundation is doing not only in juvenile entertainment but also in education and training. We came away somewhat confused, how. ever, because each film immediately followed the one shown previously. It occurred to us that if this is the usual practice at children's film matinees then young audiences probably miss some points through such confusion. We know that a crowd of children is impatient when waiting for their entertainment and frequently show their impatience in no uncertain way; but we suggest that a period of three to five minutes might be allowed to elapse between one film and the next. The interval could be filled by some properly organized community singing which the Foundation might consider fostering in the form of very short films of folk songs and traditional and national airs. The words and music could appear on the screen (with an appropriate scenic backgroundstill or moving), and the audience conducted by some form of pointer such as a bouncing white ball passing along the lines of words. From a collection of such community-singing films, those organizing a children's matinee could select the most appropriate song. For example, "The Secret Cave" could have been preceded by "A Farmer's Boy", and "A Letter from Wales" by "Men of Harlech" or "Land of my Fathers".

So far as the films are concerned, we must say that if all films witnessed by children were of the same excellent entertainment and teaching value and of the same artistic merit as those of the Children's Film Foundation, then we should soon begin to hear less about the cinema being one of the contributory causes of juvenile delinquency and more of its considerable value as a visual aid.

Details of the objectives and organization of the Children's Film Foundation can be obtained from Mr. W. G. R. Thom, Children's Film Foundation, Ltd., 73 Newman Street, London, W.1. 